\title{
Ultrastructure of the digestive system of Ramazzottius tribulosus and Macrobiotus richtersi (Eutardigrada) in relationship with diet
}

\author{
Alexandra M. AVDONINA*, Natalia M. BISEROVA ${ }^{1)}$, Roberto BERTOLANI ${ }^{2)}$ and Lorena REBECCHI ${ }^{2)}$ \\ Laboratory of Ecological Parasitology, Institute for Biology of Inland Waters, Borok, Yaroslavl district, Russia \\ ${ }^{1)}$ Department of Invertebrate Zoology, Moscow State University, Moscow, Russia \\ ${ }^{2)}$ Department of Animal Biology, University of Modena and Reggio Emilia, Modena, Italy \\ *e-mail corresponding author: aaleksandra@fromru.com
}

\begin{abstract}
The ultrastructure of the digestive system of tardigrades was already described in some species, but it has never been studied in relationship to diet. We performed ultrastructural analyses of the midgut and hindgut of phytophagous Ramazzottius tribulosus and zoophagous Macrobiotus richtersi. In addition, the foregut of R. tribulosus was analyzed. New ultrastructural details have been observed. Among them are: (a) distinct transverse pillar-like structures, lacking in electron-dense and compact cuticle of the buccal tube; (b) a hole or groups of holes sometimes present in the buccal tube; (c) a large cavity within each of the salivary glands where secreted mucus accumulates; and (d) already found in zoophagous Isohypsibius prosostomus, one valve, formed by folds of the pharynx and located at the transition from pharynx to esophagus. In both analyzed species the increase of midgut surface is identified by two orders of folds of the gut wall and by microvilli. In R. tribulosus there are many first-order folds and few second-order folds, whereas in M. richtersi the opposite pattern is found. A peritrophic membrane and microvilli with a well developed glycocalyx are found only in the midgut lumen of $\mathrm{R}$. tribulosus. The density of microvilli and the ratio between the real surface with microvilli and the hypothetical surface without microvilli is lower in zoophagous M. richtersi and I. prosostomus than in phytophagous R. tribulosus. All of these data represent an indirect indication of differences in digestive physiology between phytophagous and zoophagous tardigrade species. The shape of the hindgut is similar in both species and the lumen of the hindgut looks like a heartshaped cavity with some narrow cell evaginations.
\end{abstract}

Key words: ultrastructure, digestive system, diet, Eutardigrada

\section{INTRODUCTION}

The ultrastructure of the digestive system of tardigrades has been analyzed in several species. In particular, detailed descriptions were made for two hypsibiids, namely Thulinius augusti (Murray, 1907) [or possibly Pseudobiotus megalonyx] and Isohypsibius prosostomus Thulin, 1928 (Greven 1976; Avdonina \& Biserova 2003), and for one milnesiid, namely Milnesium tardigradum Doyère, 1840 (Dewel \& Clark 1973 a, b, c; Dewel \& Dewel 1979). Other papers have considered two other hypsibiids, Ramazzottius oberhaeuseri (Doyère, 1840) and Halobiotus crispae Kristensen, 1982 (Kinchin 1990; Eibye-Jacobsen 1996, 1997, 2001), one macrobiotid, Macrobiotus hufelandi Schultze, 1834 (see Shaw 1974; Walz 1975) and two heterotardigrades, namely echiniscid heterotardigrade Echiniscus viridissimus Péterfi, 1956 (see Dewel et al. 1988; Dewel \& Eibye-Jacobsen 2006) and halechiniscid Actinarctus doryphorus Schulz, 1935 (see EibyeJacobsen 2001). In this latter group of papers, authors analyzed only some regions or details of the digestive system.

According to Hallas \& Yeates (1972), the width of the buccal tube of tardigrades is correlated with different types of diet of the species. A correlation between the ultrastructure of the digestive system and diet has not yet been evaluated. For this reason, comparative ultrastructural analyses of the digestive system of a phytophagous and of a zoophagous eutardigrade species were performed.

\section{METHODS}

Two eutardigrade species of two different families differing in diet were studied utilizing transmission electron microscopy (TEM). A bisexual population of Ramazzottius tribulosus Bertolani \& Rebecchi, 1988 (Hypsiibidae) was collected in a moss sample from Rossena (Reggio Emilia, Italy). According to Bertolani \& Rebecchi (1988), R. tribulosus is a sibling species of Ramazzottius oberhaeuseri (Doyère, 1840), a phytophagous species feeding on Pseudochlorella, Chlorella and fragmented moss (Baumann 1966; Morgan 1977). $R$. tribulosus is also a phytophagous species.

A bisexual population of Macrobiotus richtersi Murray, 1911 (Macrobiotidae) was collected in hazelnut leaf litter from Formigine (Modena, Italy). This species is zoophagous. It is known that $M$. richtersi predates nematodes, rotifers, and also other tardigrade species (Guidetti \& Bertolani 2001; Hohberg \& Traunspurger 2005).

For both species the ultrastructure of the midgut and hindgut has been considered. In addition, we considered 
the ultrastructure in the foregut of $R$. tribulosus. Only males have been utilized.

In toto specimens were placed in $0.1 \mathrm{M} \mathrm{Na-cacody-}$ late buffer at $\mathrm{pH} 7.2$, and their cuticles were punctured. They were then submitted to primary fixation in a $2.5 \%$ glutaraldehyde solution in a $0.1 \mathrm{M} \mathrm{Na}$-cacodylate buffer at $\mathrm{pH}$ of 7.2 for $2 \mathrm{~h}$ at $4{ }^{\circ} \mathrm{C}$, washed in the same buffer, and post-fixed in $1 \% \mathrm{OsO}_{4}$ solution in a $0.1 \mathrm{M} \mathrm{Na}$ cacodylate buffer at a $\mathrm{pH}$ of 7.2 for $1 \mathrm{~h}$ at $4{ }^{\circ} \mathrm{C}$. The specimens were then dehydrated in a graded acetone series. The animals were pre-stained overnight in $0.3 \%$ uranyl acetate in $70 \%$ acetone, and then the animals were embedded in an epoxy resin (Durcopan ACM). The ultrathin sections were stained with lead citrate for $10 \mathrm{~min}$ and examined in a JEM-100C (JEOL) at the Electron Microscopy Center of the I.D. Papanin Institute for the Biology of Inland Waters of the Russian Academy of Sciences (IBIW RAS).

To find the adsorption ability of midgut, we used the Biserova \& Smetanin (1982) method of calculating the adsorption ability of cestode tegument. By considering a microvillum as a cylinder, we calculated the ratio of a defined area surface of midgut with microvilli to that of a hypothetical equivalent area without microvilli.

\section{RESULTS}

\subsection{Ramazzottius tribulosus}

\subsubsection{Foregut}

The buccal ring is round in cross-section (Fig. 1a). Its external diameter is larger than that of the buccal tube which follows. The cuticle of the buccal ring is trilayered. Transverse and electron-dense pillar-like structures (Fig. 1a) have been observed within the cuticle of the buccal ring.

The buccal tube is narrow and slightly bent. In cross-section its shape changes from round to oval. The cuticle of the buccal tube forms a pair of double hooklike structures. These structures are located dorsally and ventrally with respect to the buccal tube and function in muscle attachment along the buccal tube (Fig. 1b). Four pocket-like areas contain nerve processes extending from sensory organs to the cerebrum (Fig. 1b). Laterally and between the pocket-like areas, cuticle of the buccal tube forms a stylet-sheath on each side. The cuticle of the stylet-sheath is not homogeneous (Fig. 1b). In crosssection, the apical part of the stylet-sheath has an oval shape, whereas their basal part is pear-shaped. The lumen of the stylet-sheath is filled with electron-dense material.

Throughout the length of the buccal tube, its cuticle is electron-dense and compact, without pillar-like structures as those found at the level of the buccal ring. A hole or groups of holes are present anterior to the stylet supports (Fig. 1c). Under these parts, laterally and at each side of the buccal tube, stylets and stylet supports are present. In the stylets it is possible to recognize an apical wide part with a thin cuticle (Fig. 1c) appear- ing less electron-dense than the basal part of the stylet (Fig. 1d). Stylets do not have holes. In the specimen considered, stylets and stylet supports were located inside the cavities of the salivary glands (Figs 1c and 1d).

On each side of the buccal tube are salivary glands with a large cavity where secreted mucus accumulates. The mucus is not homogeneous because several scattered areas of different sizes are visible. There is no limiting membrane and the areas contain electron lucent material (Figs 1c and 1d). In the specimen examined, stylets and stylet supports are in direct contact with the mucus of each cavity and are not surrounded by cytomembranes. Each salivary gland is surrounded by thin muscle processes and by neuromuscular contacts (Figs 1c and 1d).

The pharynx is made up by myoepithelial cells and is surrounded by a basal membrane thicker than those of the esophagus and midgut (Figs 1e and 1f). The beginning of the pharynx is characterized by cuticular apophyses that are joined with the end of the buccal tube by thin cuticular connections (Fig. 1e). The cuticle of the apophyses is homogenous as those of the posterior part of the buccal tube and of the macroplacoids (Fig. 1e) which follow. The tri-radiated lumen of the pharynx is limited by a tri-layered cuticle. Myoepithelial pharyngeal cells contain a several mitochondria concentrated under the cuticle of the pharynx (Fig. 1e). At the transition from the pharynx to the esophagus, there is one valve made up by folds in the pharynx (Fig. 1f). The esophagus also has a tri-radiate lumen which like the rest of the foregut has a cuticular lining (Fig. 2a) which is thinner than the lining of the pharynx. The epithelial cells of the esophagus include some large vacuoles and an abundance of rough endoplasmatic reticulum (RER). The basal surface of the esophageal epithelium is practically flat and has no basal labyrinth.

\subsubsection{Midgut}

The wall of the midgut is formed by a basal membrane with one layer of large epithelial cells. Epithelial cells exhibit large nuclei, a Golgi apparatus with numerous dictyosomes, many small and large vacuoles, electron-dense inclusions, and well developed RER which do not form concentric whorls (Figs $2 b$ and 2c). Spaces without cellular material are frequently located between two epithelial cells (Fig. 2c). The surface of the midgut is enlarged by the presence of a high number of folds extending the length of the midgut. There are many first-order folds and a few second-order folds. The apical surface of the epithelial cells exhibits many microvilli (111 per $\mu^{2}$ ) forming a regular brush border (Fig. 2c). Microvilli are about $477 \mathrm{~nm}$ in length and 65 $\mathrm{nm}$ in width. They have a well developed glycocalyx that filling all spaces between them (Fig. 2c). In crosssection the microvilli form very compact hexagonal, honeycomb-shaped cells (each microvillum is surrounded by six) (Figs $2 \mathrm{~b}$ and 2c). 

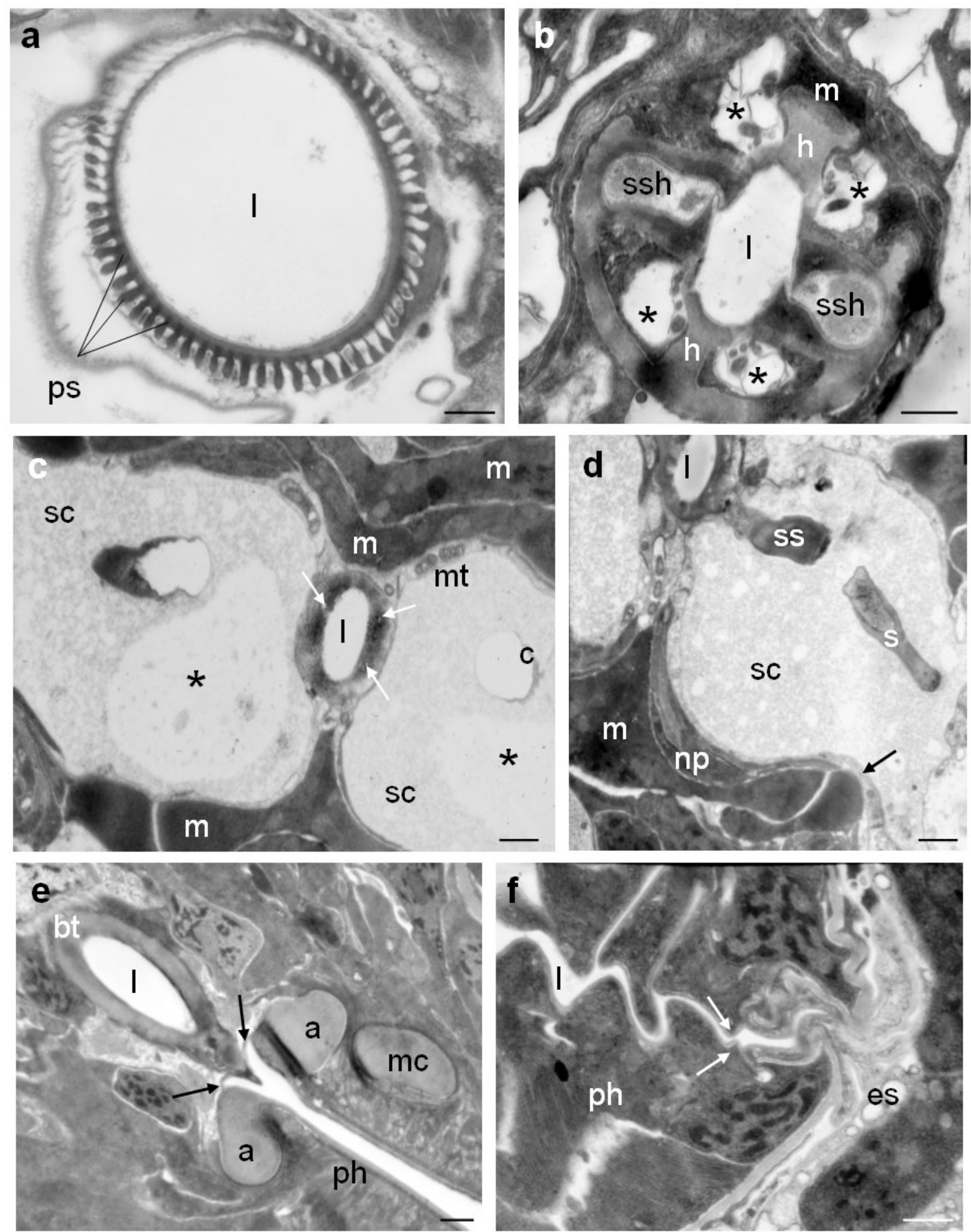

Fig. 1. Cross-sections of the digestive system of Ramazzottius tribulosus (TEM). a: Buccal ring with pillar-like structures. b: Buccal tube just under the buccal ring; note the presence of hooks, stylet sheaths and pocket-like structures $(*)$ around the buccal lumen. c: Salivary cavities of the salivary glands around the buccal tube; note the heterogeneous aspect of the mucus $(*)$ and the presence of holes in the cuticle of the buccal tube (arrows). d: Stylet and stylet support within a salivary cavity; note the thin layer (arrow) of the salivary gland. e: Valve (apophyses) and cuticular connection (arrows) between buccal tube and pharynx. f: Transition area between pharynx and esophagus with evident valve (arrows). a: apophysis, bt: buccal tube, c: cuticle, es: esophagus, h: hook-like structure, l: lumen, m: muscle, mc: macroplacoid, mt: mitochondrion, $\mathbf{n p : ~ n e r v o u s ~ p r o c e s s e s , ~ p h : ~ p h a r y n x , ~ p s : ~ p i l l a r - l i k e ~ s t r u c t u r e s , ~ s : ~ s t y l e t , ~ s c : ~}$ salivary cavity, ss: stylet support, ssh: stylet sheath. Scale bars: $1 \mu \mathrm{m}$. 

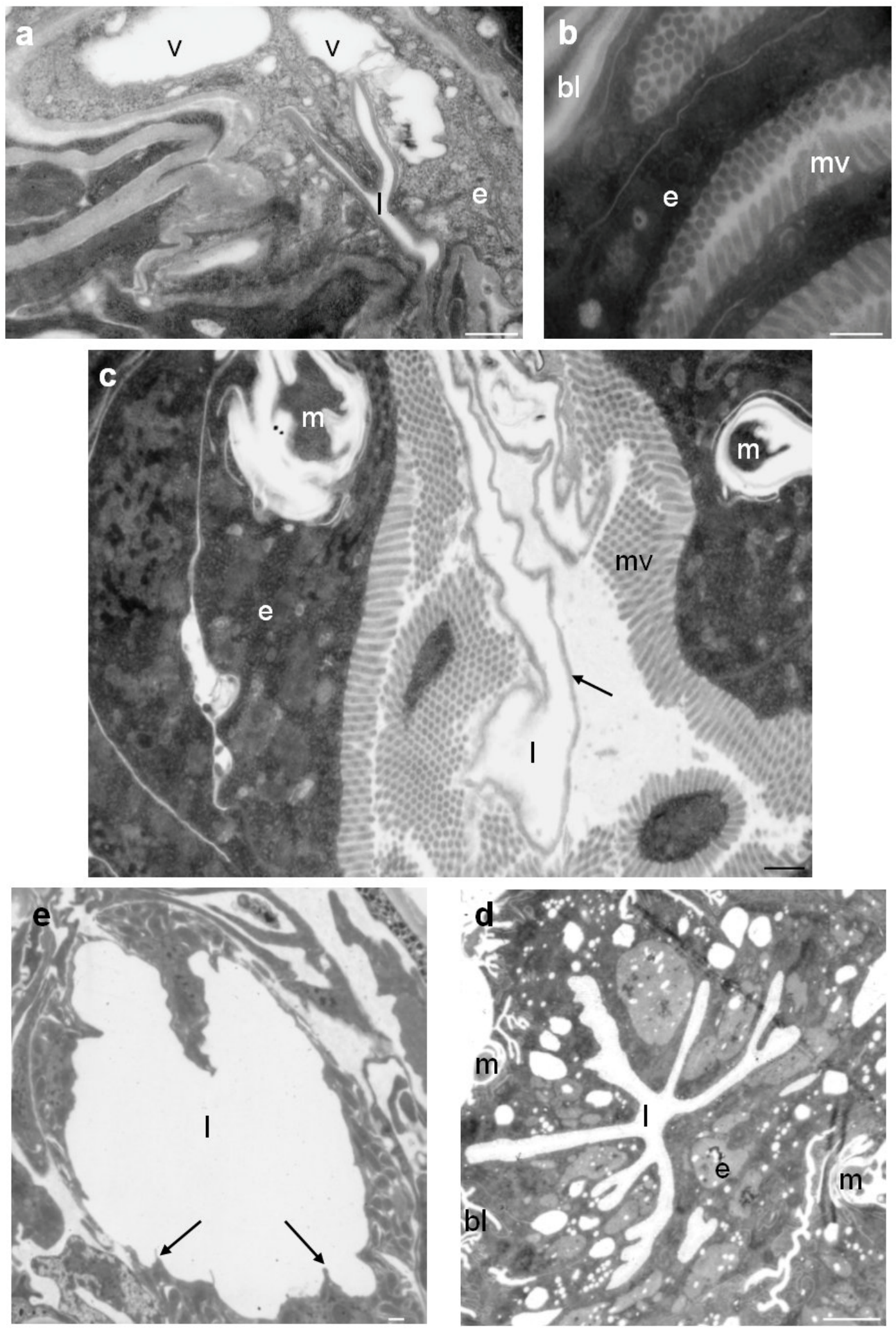

Fig. 2. Ramazzottius tribulosus (TEM). a: Tri-radiate lumen of the esophagus. b-c: Midgut with microvilli; note the presence of the peritrophic membrane (arrow). d: Hindgut with small evaginations (arrows). e: Midgut of Macrobiotus richtersi (TEM). bl: basal labyrinth, I: lumen, ph: pharynx, v: vacuole, e: epithelial cell, m: muscle, mv: microvilli. Scale bars: $1 \mu \mathrm{m}$. 
The ratio between the real surface of a midgut with microvilli and a hypothetic surface without microvilli is 11.5. The midgut lumen exhibits a peritrophic membrane (Fig. 2c). Cells of the posterior part of the midgut have a well developed basal labyrinth (Fig. 2b).

\subsubsection{Hindgut}

The lumen of the hindgut is lined by a thin tri-layered cuticle. In cross-section it appears as a big heartlike cavity with some narrow evaginations (Fig. 2d). These evaginations are formed by cells sometimes containing a large, lobed nucleus with a large nucleolus. The cytoplasm of these hindgut cells is rich in RER, free ribosomes, and numerous small electron-dense granules. Mitochondria are concentrated under the apical cell surface. The cell surface has many indentations of plasmalemma which form channels penetrating the cuticle of the rectum lumen.

\subsection{Macrobiotus richtersi}

\subsubsection{Midgut}

In cross-section the lumen of the midgut resembles a star due to the presence of large symmetrical folds (diverticula) formed by the apical surface of large epithelial cells (Fig. 2e). In the midgut, folds have two orders: (a) large, broad first-order folds, and (b) slender second-order folds. First-order folds are few, while there are many second-order folds. At the bases of second-order folds, numerous small and large vacuoles were usually found. The content of vacuoles has different electron-densities. Epithelial cells include large nuclei, mitochondria, and abundant RER. Microvilli are about $362 \mathrm{~nm}$ in length and $45 \mathrm{~nm}$ in width. The density of microvilli is 73 per $\mu \mathrm{m} 2$ and in cross-section their hexagonal arrangement is not evident. Glycocalyx is present but not particularly developed. The ratio between the real surface of the midgut with microvilli and the hypothetical surface without microvilli is 4.6.

\subsubsection{Hindgut}

The lumen of the rectum is lined by cuticle forming heart-like structures in cross-section with some narrow cell evaginations. The cells of the hindgut contain numerous small electron-dense granules.

\section{DISCUSSION}

In tardigrades the buccal ring is part of the mouth. In $R$. tribulosus the cuticle of the buccal ring forms transverse pillar-like structures which are lacking in the walls of the buccal tube. Similar structures were described by Dewel \& Eibye-Jacobsen (2006) in the heterotardigrade E. viridissimus. In both species the pillar-like structures are located only in the buccal ring cuticle. Functionally, these structures could be a light skeleton maintaining the form of the mouth opening. The pillar-like structures are not homologous to the columns (pillars) noted in the dorsal cuticle of many heterotardigrades (Kristensen 1976, 1978; Kristensen \& Neuhaus 1999) and in some eutardigrades (Kristensen 1982; Dastych 1997; Guidetti et al. 2000).

The cuticle of the buccal tube of $R$. tribulosus is characterized by the presence of holes or groups of holes. Dewel and Clark (1973a) found several vacuoles in the cuticle of the buccal tube of $M$. tardigradum. In regard to the function of these structures, we can hypothesize two possibilities: (a) holes or vacuoles make the cuticular structure lighter, and (b) they represent canals through which nerve processes pass. In $R$. tribulosus, due to the small size of the holes, the latter explanation is more probable.

Morphology of the stylet-sheath found in R. tribulosus allows movement of the stylets and prevents hanging of stylets from the stylet-sheaths. The stylet-sheaths are filled with mucus similar to that of the salivary glands indicating a connection between salivary glands and stylet-sheaths.

Salivary cavities in salivary glands of $R$. tribulosus accumulate mucus of different densities as in salivarium of insects (Chapman 1998). Three hypotheses have been formulated to explain the different aspects of the mucus in the salivary cavities of tardigrades. According to Marcus (1929), it is a result of the secretion of two different products. According to Dewel \& Clark (1973a), it is either a result of different stages of mucous secretion or it is an artifact of the fixation. Unfortunately, our data cannot confirm if one of these hypotheses is applicable to R. tribulosus.

Stylets of tardigrades may contain calcium carbonate (Nielsen 1995; Bird \& McClure 1997). Dewel \& Clark (1973a) noted that stylets of zoophagous M. tardigradum have holes containing a secretion similar to that of the salivary glands but they do not have evidence of the presence of narcotizing or poisoning agents. In phytophagous $R$. tribulosus stylets do not have holes. The difference in stylet structure between these two species could be connected to the different diet. The presence of stylets and stylet supports inside cavities of salivary glands may be explained because we examined a specimen in the final molting stage.

Usually cuticular folds of the pharynx function as a valve (Dewel \& Clark 1973b; Eibye-Jacobsen 1997). A similar pattern was found in $R$. tribulosus. Ultrastructural analysis of the foregut of $R$. tribulosus gives us the ability to identify an interesting structure located at the transition area between the pharynx and esophagus that works as a valve. This finding confirms the role of a similar structure described for the first time in I. prosostomus by Avdonina \& Biserova (2003). Since I. prosostomus is zoophagous, we can conclude that the presence of this valve is not related to animal diet. Its function is to hinder any food from flowing back because the foregut is lined by a cuticle and is incapable of peristaltic movements. The opening and the closing of the 
valves in turn provides the difference in pressure from different parts of the foregut. Therefore, the presence of valves is very important in organizing and directing food transport. The myoepithelial pharynx is significant in that it functions as a pump in food transport. This function is possible because of energy produced either by numerous mitochondria concentrated under the cuticle of the pharynx as in $R$. tribulosus or by the abundance of mitochondria located near the lumen and outer surface of the pharynx (M. tardigradum, Dewel \& Clark 1973a).

As noted by Greven (1976) for Thulinius augusti (or Pseudobiotus megalonyx), the midgut surface is made wider by large folds of the gut wall. This pattern was present in $R$. tribulosus and M. richtersi. Nevertheless, the two species differ both in the organization and in the number of first- and second-order folds.

Adsorption surface depends on the number of gut folds and the number of microvilli. In general in tardigrades, microvilli are present on the surface of the midgut epithelium cells with the hexagonal shape providing the most compact form of organization (Dewel et al. 1993). Microvilli density varies among the species. Density is higher in phytophagous $R$. tribulosus than in zoophagous $M$. richtersi and $I$. prosostomus (81 per $\mu \mathrm{m}^{2}$; Avdonina \& Biserova 2003). Microvilli of $M$. richtersi are shorter and thinner than those of $R$. tribulosus which are similar in length and width to those of $I$. prosostomus. More important is the ratio between the real surface with microvilli and the hypothetical surface without microvilli. This ratio is higher in R. tribulosus (11.5) than in M. richtersi (4.6) and I. prosostomus, (9) (Avdonina \& Biserova 2003). These data allow us to identify differences in ultrastructure of the midgut in relation to food. According to Ugolev (1967) extension of the gut area by microvilli is an indirect indication of intensification of adsorption ability. For phytophagous tardigrade species, extension of gut surface by microvilli is greater than that of zoophagous species. Ugolev (1967) affirms that a high density of microvilli with a well developed glycocalyx and presence of a peritrophic membrane are indications of active membrane digestion. Our investigation observed these structures in $R$. tribulosus. All of these data represent an indirect indication of differences in digestive physiology between phytophagous and zoophagous tardigrade species.

As we supposed, relevant differences have not been found in the ultrastructure of epithelial cells and rectums among $M$. richtersi, $R$. tribulosus, and M. tardigradum because the hindgut is not directly involved in food digestion.

\section{ACKNOWLEDGMENTS}

We are grateful to Zinaida Panova and Gregory Bikov for their technical supports and Sergei Metelev, the head of Electron Microscopy Center of the Institute for the Biology of Inland Waters of the Russian Acad- emy of Sciences. In addition, the authors are grateful to Juliana Hinton for English revision and anonymous reviewers for their useful comments. Investigations are supported by INTAS Grant N. 04-83-3807.

\section{REFERENCES}

Avdonina, A.M. \& N.M. Biserova. 2003. The morpho-functional characteristics of the foregut and midgut of Isohypsibius prosostomus Thulin, 1928 (Eutardigrada) in connection with the peculiarities of food. Biol. Inland Waters, 3: 45-53 (in Russian).

Baumann, H. 1966. Lebenslauf und Lebensweise von Hypsibius (H.) oberhaeuseri Doyère (Tardigrada). Veröff. Überseemus. Bremen, 3: 245-258.

Bertolani, R. \& L. Rebecchi. 1988. The tardigrades of Emilia (Italy). I. Rossena. Boll. Zool., 55: 367-371.

Bird, A.F. \& S.G. McClure. 1997. Composition of the stylets of the tardigrade, Macrobiotus cf. pseudohufelandi. Trans. R. Soc. S. Aust., 121: 43-50.

Biserova, N.M. \& M.M. Smetanin. 1982. About accuracy of increase body surface determination in Acanthobothrium dujardini (Cestoda: Tetraphyllidea). Estimation of errors for methods of hydrobiological and icthyological investigations. Rybinsk, Russia, IBIW RAS: 156-161 (in Russian).

Chapman, R.E. 1998. The insects: structure and function. 4th Ed. Cambridge University Press, Cambridge: $770 \mathrm{pp}$.

Dastych, H. 1997. Redescription of Isohypsibius sculptus Ramazzotti, 1962 (Tardigrada). Entomol. Mitt. zool. Mus. Hamburg, 12: 163-167.

Dewel, R.A. \& Jr.W.H. Clark. 1973a. Studies on the tardigrades. I. Fine structure of the anterior foregut of Milnesium tardigradum Doyère. Tissue and Cell, 5: 133-146.

Dewel, R.A. \& Jr.W.H. Clark. 1973b. Studies on the tardigrades. II. Fine structure of the pharynx of Milnesium tardigradum Doyère. Tissue and Cell, 5: 147-159.

Dewel, R.A. \& Jr.W.H. Clark. 1973c. Studies on the tardigrades. III. Fine structure of the esophagus of Milnesium tardigradum Doyère. Tissue and Cell, 5: 161-169.

Dewel, R.A. \& W.C. Dewel. 1979. Studies on the tardigrades. IV. Fine structure of the hindgut of Milnesium tardigradum Doyère. J. Morphol., 161: 79-110.

Dewel, R.A. \& J. Eibye-Jacobsen. 2006. The mouth cone and mouth ring of Echiniscus viridissimus Peterfi, 1956 (Heterotardigrada) with comparisons to corresponding structures in other tardigrades. Hydrobiologia, 558: 41-51.

Dewel, R.A., D.R. Nelson \& W.C. Dewel. 1993. Tardigrada. In: F.H. Harrison \& M.E. Rice (Eds), Microscopic Anatomy of Invertebrates: Onychophora, Chilopoda and Lesser Protostomata, 12. J. Wiley-Liss, Inc, New York: 143-183.

Dewel, R.A., B.G. Roush \& W.C. Dewel. 1988. Fine structure of the midgut cells of the heterotardigrade Echiniscus viridissimus. Am. Zool., 28: 149.

Eibye-Jacobsen, J. 1996. On the nature of pharyngeal muscle cells in the Tardigrada. Zool. J. Linn. Soc., 116: 123-138.

Eibye-Jacobsen, J. 1997. Development, ultrastructure and function of the pharynx of Halobiotus crispae Kristensen, 1982 (Eutardigrada). Acta Zool., 78: 329-347.

Eibye-Jacobsen, J. 2001. Are the supportive structures of the tardigrade pharynx homologous throughout the entire group? J. Zool. Syst. Evol. Res., 39: 1-11.

Greven, H. 1976. Some ultrastructural observations on the midgut epithelium of Isohypsibius augusti (Murray, 1907) (Eutardigrada). Cell Tissue Res., 166: 339-351.

Guidetti, R. \& R. Bertolani. 2001. The tardigrades of Emilia (Italy). III. Piane di Mocogno (Northern Apennines). Zool. Anz., 240: 377-383. 
Guidetti, R., L. Rebecchi \& R. Bertolani. 2000. Cuticle structure and the systematics of Macrobiotidae (Tardigrada, Eutardigrada). Acta Zool., 81: 27-36.

Hallas, T.E. \& G.W. Yeates. 1972. Tardigrada of the soil and litter of a Danish beech forest. Pedobiologia, 12: 287-304.

Hohberg, K. \& W. Traunspurger. 2005. Predator-prey interaction in soil food web: functional response, size-dependent foraging efficiency, and the influence of soil texture. Biol. Fertil. Soils, 41: 419-427.

Kinchin, I.M. 1990. Observations on the structure of Ramazzottius (with a Checklist of British Eutardigrada). Microscopy, 36: 475-482.

Kristensen, R.M. 1976. On the fine structure of Batillipes noerrevangi Kristensen 1976. 1. Tegument and moulting cycle. Zool. Anz., 197: 129-150.

Kristensen, R.M. 1978. On the fine structure of Batillipes noerrevangi Kristensen 1976. 2. The muscle-attachments and the true cross-striated muscles. Zool. Anz., 200: 173184.

Kristensen, R.M. 1982. New aberrant eutardigrades from homothermic spring on Disco Island, West Greenland. In: D.R. Nelson (Ed.), Proceedings Third International Sym- posium on the Tardigrada. East Tennessee State University Press, Johnson City, Tennessee: 203-220.

Kristensen, R.M. \& B. Neuhaus. 1999. The ultrastructure of the tardigrade cuticle with special attention to marine species. Zool. Anz., 238: 261-281.

Marcus, E. 1929. Tardigrada. In: H.G. Bronn (Ed.), Klassen und Ordnungen des Tierreichs. Vol. 5. Abt. IV. Buch. 3, Akademische Verlagsgesellschaften, Leipzig: 1-608.

Morgan, C.I. 1977. Population dynamics of two species of Tardigrada, Macrobiotus hufelandi (Schultze) and Echiniscus (Echiniscus) testudo (Doyère), in roof moss from Swansea. J. Anim. Ecol., 46: 263-279.

Nielsen, C. 1995. Animal evolution: interrelationships of the living phyla. Oxford University Press, Oxford, New York, Tokyo: $467 \mathrm{pp}$.

Shaw, K. 1974. The fine structure of muscle cells and their attachments in the tardigrade Macrobiotus hufelandi. Tissue and Cell, 6: 431-445.

Ugolev, A.M. 1967. The physiology and pathology of the membrane (contact) digestion. Nauka, Leningrad, Russia: 230 pp. (in Russian).

Walz, B. 1975. Ultrastructure of muscle cells in Macrobiotus hufelandi. Mem. Ist. ital. Idrobiol., 32: 425-443. 